NBSIR 74-582

FY 1973 Progress Report on Design Criteria and Methodology for Construction of Low-Rise Buildings to Better Resist Typhoons and Hurricanes

N. J. Raufaste and R. D. Marshall

Center for Building Technology

Institute for Applied Technology

$N$ ational Bureau of Standards

Washington, D. C. 20234

July 2, 1973

Prepared for

The Office of Science and Technology Agency for International Development

Department of State

Washington, D. C. 20234

Under a Participating Agency Service

Agreement (PASA)

No. TA (CE) 04-73 


\section{FY 1973 PROGRESS REPORT ON DESIGN CRITERIA AND METHODOLOGY FOR CONSTRUCTION OF LOH-RISE BUILDINGS TO BETTER RESIST TYPHOONS AND} HURRICANES

N. J. Raufaste and R. D. Marshall

Center for Building Technology Institute for Applied Tecinnology National Bureau of Standards Washington, D. C. 20234

July 2, 1973

Prepared for

The Office of Science and Technology Agency for International Development

Department of State

Washington, D. C. 20234

Under a Participating Agency Service Agreement (PASA)

No. TA (CE) 04-73

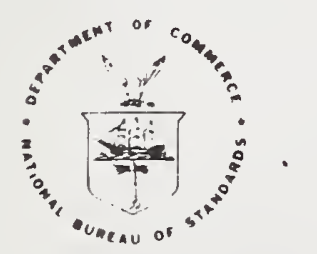

U. S. DEPARTMENT OF COMMERCE, Froderick B. Dent, Secretary 
)

1 


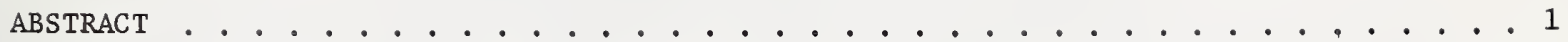

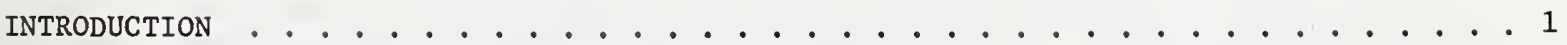

A. SUMMARY OF PROGRESS FOR FISCAL YEAR 1973.................. 2

Field Trip . . . . . . . . . . . . . . . . . . . . . . 2

Tokyo, Japan ..................... . . 3

Manila, Philippines .................. 3

Dacca, Bangladesh . . . . . . . . . . . . . . . . 8

Garston, Watford, England . . . . . . . . . . . . 13

Sydney, Australia . . . . . . . . . . . . . . 14

Melbourne, Australia . . . . . . . . . . . . . . . . 14

NBS Fiscal Year 1973 Equipment Purchases . . . . . . . . . . . 15

Identification of Related Documents . . . . . . . . . . . . 16

B. PROJECTED ACTIVITIES FOR FISCAL YEAR $1974 \ldots \ldots \ldots$

Transfer of Information . . . . . . . . . . . . . . . 16

Visit to Northern Caribbean Islands . . . . . . . . . . . . 17

Purchase of Equipment in Fiscal Year 1974 . . . . . . . . . . . . . 17

Identification of Fleld Test Sites . . . . . . . . . . . . . 17

Climatological Analysis of Data................. . . 18

Wind Tunnel Studies....................... . 18

C. PRELIMINARY FISCAL YEAR 1974 PROJECT SCHEDULE . . . . . . . . . . . . . . . . 19

APPENDIX A: ORGANIZATIONS AND FACILITIES VISITED DURING THE

APRIL 1973 FIELD TRIP . . . . . . . . . . . . . . . 22

APPENDIX B: BIBLIOGRAPHY OF DATA RELEVANT TO THE NBS/USAID WIND

PROJECT . . . . . . . . . . . . . . . . 26 


\section{SI CONVERSION FACTORS}

This report describes measurements in metric units. It is recommended that the reader assume the responsibility for applying the appropriate conversion to English units. The United States of America, as a signatory to the General Conference of Weights and Measures (which gave official status to the metric SI system of units), recognizes the International Standard (SI) unit of measurement.

\section{Length}

$$
\begin{aligned}
& 1 \text { meter }(\mathrm{m})=3.281 \text { feet }(\mathrm{ft}) \\
& 1 \text { kilometer }(\mathrm{km})=0.622 \mathrm{mile}(\mathrm{mi})
\end{aligned}
$$

\section{Velocity}

1 meter per second $(\mathrm{m} / \mathrm{s})=3.281$ feet per second (ft/s) or $2.237 \mathrm{mile}$ per hour (mi/hr) 


\section{DESIGN CRITERIA AND METHODOLOGY \\ FOR CONSTRUCTION OF LOW-RISE BUILDINGS \\ TO BETTER RESIST TYPHOONS AND HURRICANES}

by

\section{N. J. Raufaste \\ R. D. Marsha11}

Center for Building Technology

Institute for Applied Technology

National Bureau of Standards

\begin{abstract}
This report presents the major accomplishments and the initial phase of a three-year project to provide engineering technical assistance to the Agency for International Development (AID) for the development of design criteria for low-rise buildings to better withstand extreme winds. This phase represents a 3 month level of effort. During this period, the Center for Building Technology project staff members commenced six introductory tasks. These tasks will set the pace for the second fiscal year level of effort. The tasks included: (1) initiate dialogue with organizations and institutes in developing countries; (2) establish a Philippine advisory committee; (3) conduct on-site visits to developing countries to identify local professional candidates for short-term consultating; (4) conduct on-site visits to developed countries to collect information from research centers; (5) purchase initial wind tunnel and full-scale field test instrumentation; and (6) commence library search of related subject documents.
\end{abstract}

\title{
INTRODUCTION
}

Statistics show that Luzon Island, Philippines experience the highest annual frequency of extreme winds in the world. Approximately 50 percent of the Philippine population live within this area. In view of the climatology for this geographic area and the variety of problems created by the rapidly spiraling population (36.7 million people estimated by the 1970 census with an annual growth rate of 3.0 percent) ${ }^{1}$, the loss of life and property can be expected to increase in the years ahead. of the sixty eight major typhoons reported by the Philippine Weather Bureau during 1965-1971, ten had wind speeds in excess of $60 \mathrm{~m} / \mathrm{s} .2$ Post disaster reports indicate millions of dollars of property is damaged annually and hundreds of lives are lost due to these typhoons. For example, in 1970 the Philippines experienced four typhoons causing over 1000 deaths and over $\$ 45$ million damage to property, including damage to approximate1y 9000 public school classrooms. It is estimated that over 300,000 school children were affected by the storms.

In addition to the Philippines, other heavily populated geographic areas experience extreme winds; they include the Indian Ocean countries, the northern Caribbean Islands, and the southeastern United States. Frequency distributions' of extreme winds for these geographic areas indicate that the northern Philippines experiences a mean annual crossing frequency (per $5^{\circ}$ square of latitude and longitude) of 5 tropical cyclones (wind speeds greater than $17.5 \mathrm{~m} / \mathrm{s}$ ); the second geographical area experiences an annual frequency of 1.2 tropical storms per 50 square while the third and fourth experience 1.0 and 1.5 respectively.

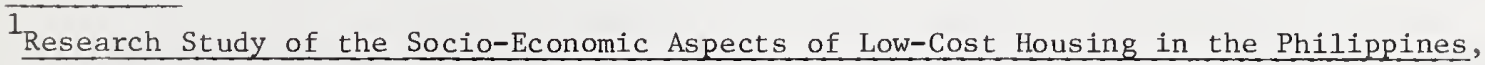
Progress Report. Sycip, Gones, Valayo and Co., March 1972.

${ }^{2}$ Ibid.
} 
While research into the effects of winds on buildings and other structures is being conducted in developed countries, very little of this research is being conducted on lowrise buildings and practically no research is being performed on low-rise buildings in developing countries. The developing countries are at a particular disadvantage since their economies usually do not permit a rebuilding of damaged structures after each storm. It is estimated that 85 percent of some developing country residents live in temporary houses made out of material found along the roadside or discarded by another person.

To assist the developing countries in these areas, AID requested the National Bureau of Standards to develop design criteria for low-rise, low-cost structures to better withstand extreme winds. AID also requested that such assistance be structured to improve the local technical expertise and research capabilities as well as to establish wind research capability in organizations and institutes in the participating countries.

As a preliminary step to this study, an AID/NBS research effort entitled, "The Design, Siting and Construction of Low-Cost Housing and Community Buildings to Better Withstand Earthquakes and Windstorms" clearly pointed out that improvements in the collection and analysis of climatological design data, strength of structural elements, building siting and its geometry, and information regarding structural connection details is needed. Such information gaps are seriously affecting building designs in many of the developing countries. The results and recommendations of the above study were considered in the planning of this study.

To date, approximately 60 different individuals were contacted in person to discuss this research to collect information relevant to the project, to help organize a Philippine advisory committee and to identify appropriate short-term consultants.

The next section of this report presents a summary of progress during fiscal year 1973 . This is followed by a discussion of the progress and plans for fiscal year 1974.

Two appendices are included:

- Appendix A: List of individuals and organizations contacted during FY'73 field visits, and

- Appendix B: A bibliography relevant to NBS/USAID wind project.

A. SUMMARY OF PROGRESS FOR FISCAL YEAR 1973

\section{Field Trip}

Philippines, Bangladesh and Jamaica were selected by USAID and NBS for participation in this study. The selection was based upon their need for assistance as well as on their potential for implementing and transferring the research results to their respective geographic areas. Japan, Australia and England representing developed countries were selected to collect information from research institutes about their experiences with similar research projects.

The events associated with this trip may be viewed as 2 separate aspects. The first was concerned with introducing the study to appropriate local individuals. These individuals were encouraged to interact with the NBS personnel so to better delineate the purpose of the research, to assess their capabilities and to answer their questions.

The second task was concerned with assessing the expertise of individuals and their organization's capability in high wind research in the participating developing countries.

\footnotetext{
"Distribution of Extreme Winds Over Oceans", Journal of the Waterways, Harbors and Coastal Engineering Division, By Herbert C. S. Thom, February 1973.
} 
On the surface, it might appear that the selected developing countries do not possess the capabilities or expertise to perform this type of research. This is not. true. They are, however, lacking in appropriate technical guidance and funding for necessary equipment and facilities.

A summary of the activities performed in each country and specifically at the local organizational leve1 is discussed below:

1. Tokyo, Japan

a. U.S. Embassy

Mr. Richard H. Zorn II, Assistant to Dr. Robert W. Hiatt, Scientific Counselor was visited at the American Embassy. Mr. Zorn was interested in the project and offered to act as liaison to identify, Japanese researchers with appropriate credentials for participation in this research. He requested copies of all relevant correspondence so he would be informed of the project status.

b. Ministry of Construction, Public Works Research Institute

This institute is involved with several wind research activities. The individuals 1isted under Appendix A part 1.b were briefed in detail on the objectives of our research. This meeting provided the opportunity to discuss the wind research project with other qualified individuals, and to identify a future potential source with which to share information. The general discussions with the Public Works officials centered around collecting similar information and a discussion of their experiences in Manila. It would be desirable to interact with the Institute. If such is agreeable with The Agency for Internationa1 Development, Washington, D. C., (AID/W) a formal, invitation should be addressed to the Institute identifying one individual for his participation. in the forthcoming organizational meeting/workshop would be desirable.

2. Manila, Philippines

a. USAID Mission

The Assistant and Deputy Assistant Directors for Capita1: Development (see Appendix A part 2.a) were visited on several occasions to discuss the joint research involvement and areas of responsibility.: Mr. Larson believed that the University is the most logical organizational group to serve as the focal point in interacting between NBS and the local Philippine agencies and organizations. This judgment is based upon the University's expertise and capabilities including their sensitivity to administrative aspects associated with this project. Mr. Larson felt the newly formed Philippine Advisory Committee has potential for raising the necessary funds for their level of activities. The AID Mission, would serve in a consultant capacity to this project and provide assistance to this committee as the need arises.

b. University of the Philippines

A meeting was scheduled with individuals from the, college of Architecture and Engineering (see Appendix A, part 2.b) to review the: research project, to discuss their participation and assess their laboratory capability and equipment inventory. A list of equipment for wind tunnel: tests and field instrumentation was developed during discussions with the Civil Engineering Department and the Computer Center staffs.

The University of Philippines (UP) wind tunnel facility and associated instrumentation were evaluated for conducting building aerodynamic studies. The tunnel is a closed return system.with a drive motor located directly above the test section. The test section is 1.22 , meters square and 3.70 meters 1ong. The fan diameter is 1.5 meters and produces a maximum wird speed of $30 \mathrm{~m} / \mathrm{s}$. Corner fillets in the tunnel are removable and provide a means for adjusting the pressure gradient. While the tunnel is quite sma11 (by current standards) for modeling 
atmosineric flows, it is probably sufficient if the growth rate of the boundary layer is stimulated or augmented. The tunnel is housed in a building having a large uncommitted floor area and the facility is used only on rare occasions. With the exception of some general-purpose equipment in the Department of Electrical Engineering, instrumentation necessary for wind tunnel studies is nonexistent.

The University operates an IBM 360 , Model 40 Computer with a memory capacity of 64,000 words. Mass storage is provided by two 2311 disk drives. Four tape drives are available; one is a 7-track and the others are 9-track. No plotting facilities or A-D conversion are available. Two line printers are used, each with a capability of printing 1200 lines per minute. CPU rates are approximately $\$ 70$ per hour for commercial work and $\$ 35$ per hour for academic work.

c. Philippine Weather Bureau

With the Weather Bureau Officials, (see Appendix A part 2.c) the research projects scope of work was reviewed and questions answered. The Bureau presently records winds at about 200 weather stations ( 50 synoptic stations, 150 climatological stations; 4 are a combination radar/synoptic station). The Weather Bureau suggested that Catanduanes Island (an island east of Luzon) is a promising candidate site for full-scale building tests since this island has a very high mean annual frequency of tropical storms.

d. National Housing Corporation (NHC)

NHC was organized in 1968 with funding from the governinent and private banks to mass produce building components. To data several hundred single family houses have been built, most constructed of porous concrete panels $(1.00 \times 2.40 \mathrm{~m})$ and galvanized iron roofing (see fig. 1). Gen. G. V. Tobias, Executive Vice President of $\mathrm{NHC}$, is very interested in the project since it could directly affect his plans for providing several thousand future homes. He offered his facilities for use as a test structure and office space for NBS staff.

e. People's Homesite and Housing Corporation (PHHC)

This Corporation is directly orfented toward providing housing for the low-income citizen. Its funding is almost solely from the Government which ultimately reduces the selling price of developed lots. Lieutenant Colonel Rebueno, representing PHHC, stated that he would follow any decisions made by the Advisory Committee and would adopt improved design criteria for housing to better withstand high winds.

f. Economic Commission for Asia and the Far East (ECAFE)

Dr. Senn, Chief, Typhoon Research Committee, is interested in this subject because of his aim and objectives as Chairman of the ECAFE Typhoon Research Committee. ECAFE is interested in the improvement of communications, flood and typhoon warning and the transfer of information to the other countries engaged in Typhoon Research (Japan, Korea, Hong Kong, Philippines, Laos, Thailand and Cambodia). His area of participation would be to transfer results of our research activities to the Typhoon Research Committee as they develop. In this manner, NBS/AID would have the benefit of additional comments and criticisms. If his assistance is requested, it should be done on an informal basis. In this respect, Dr. Senn would be more flexible in his interaction with the wind project.

g. Land and Housing Development Corporation (LHDC)

LHDC is a privately financed housing development organization providing homes primarily to low-middle and middle income families. A visit was made to one of their sites near Manila, where this corporation is constructing homes (see figs. 2 and 3) using convential building construction techniques and materials (concrete block and galvanized iron roofing). Col. A. R. Sanchez, Vice President (Operations), offered one of his houses as a test building. 


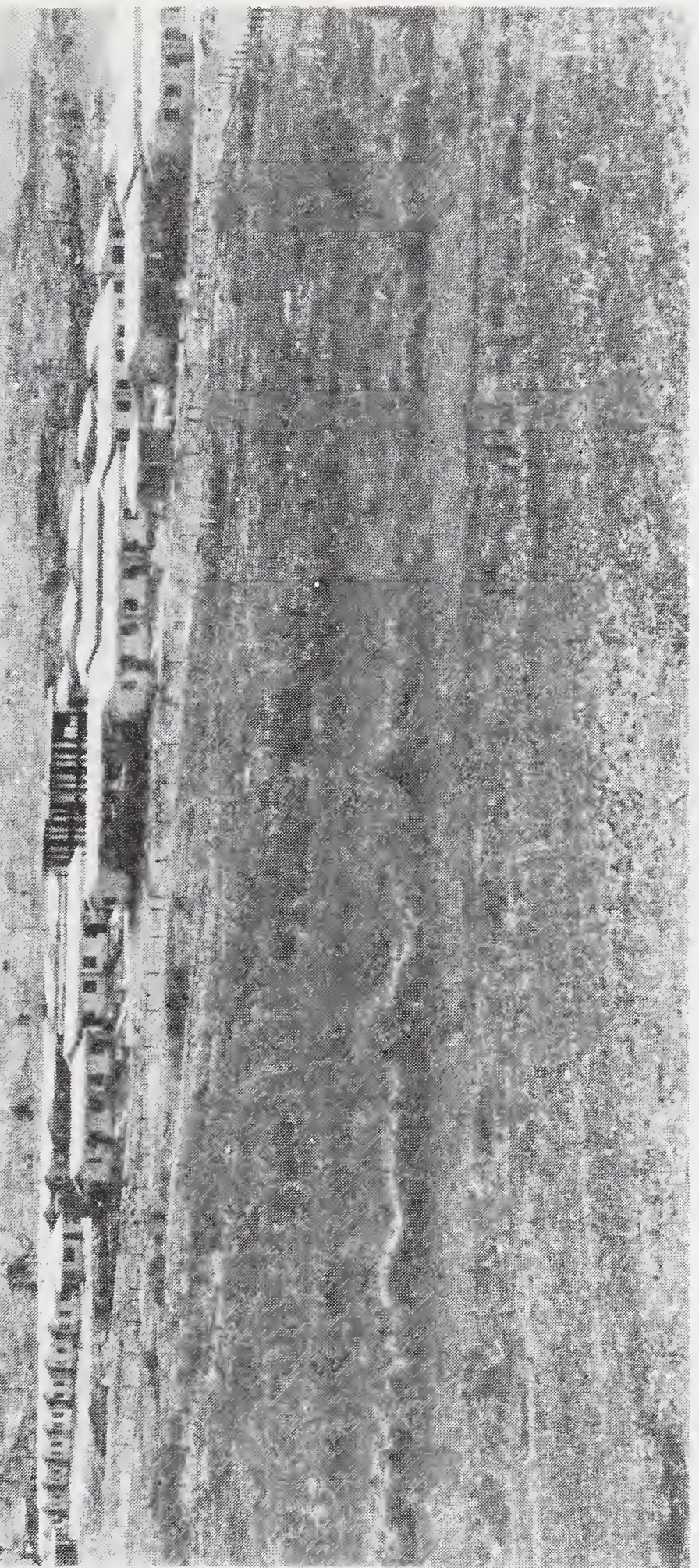

$\stackrel{\infty}{\circ} \stackrel{0}{=}$

ว

त 20

$\exists 0$

(ब)

돈

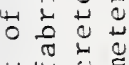

के

ช̃

西

ถั

E

DE

웡워

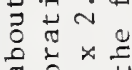

ro

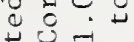

\%

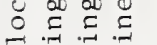

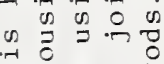

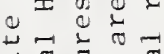

$\overrightarrow{0} \stackrel{0}{=}$ in

n.

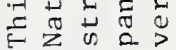

$-$

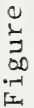




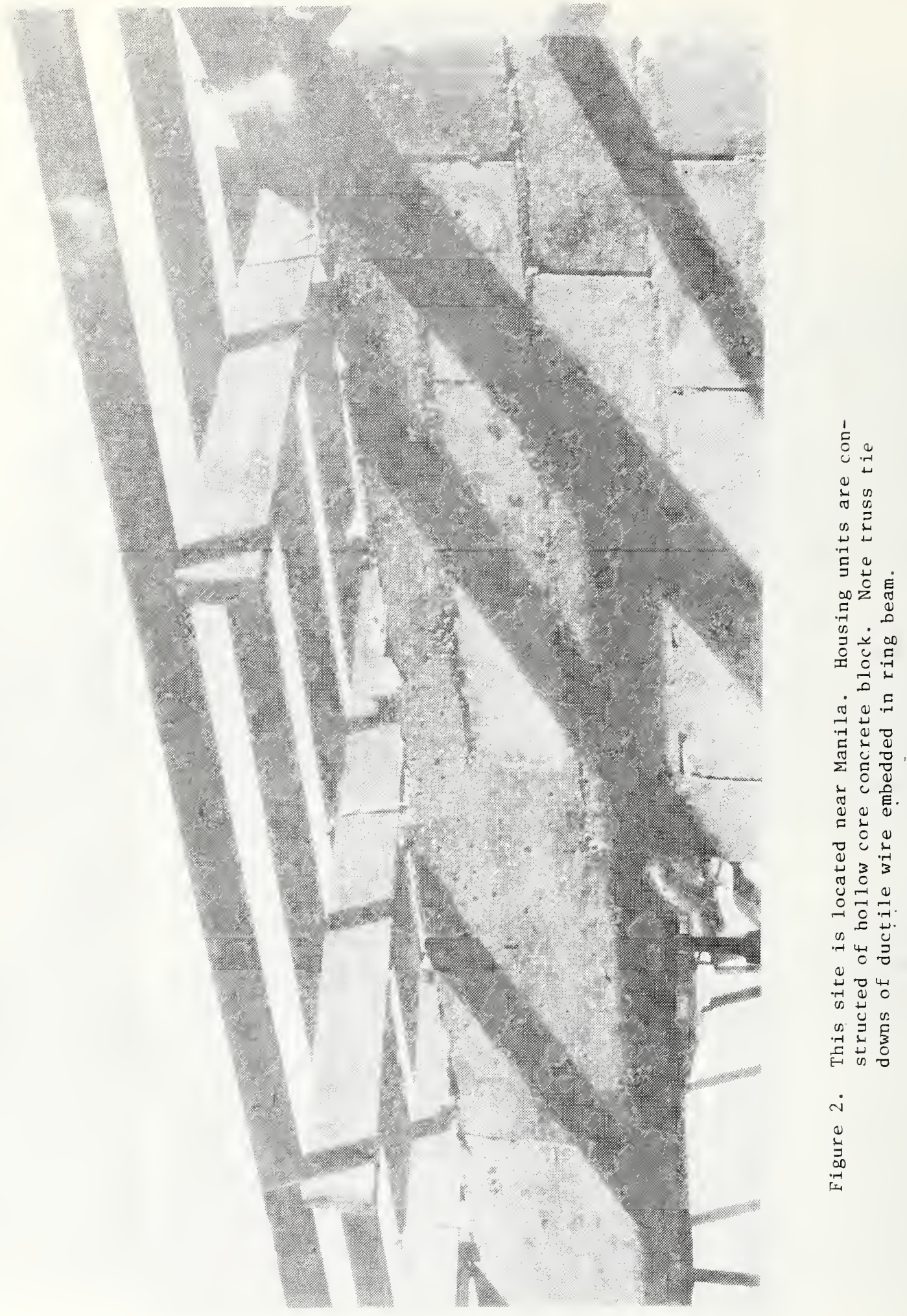




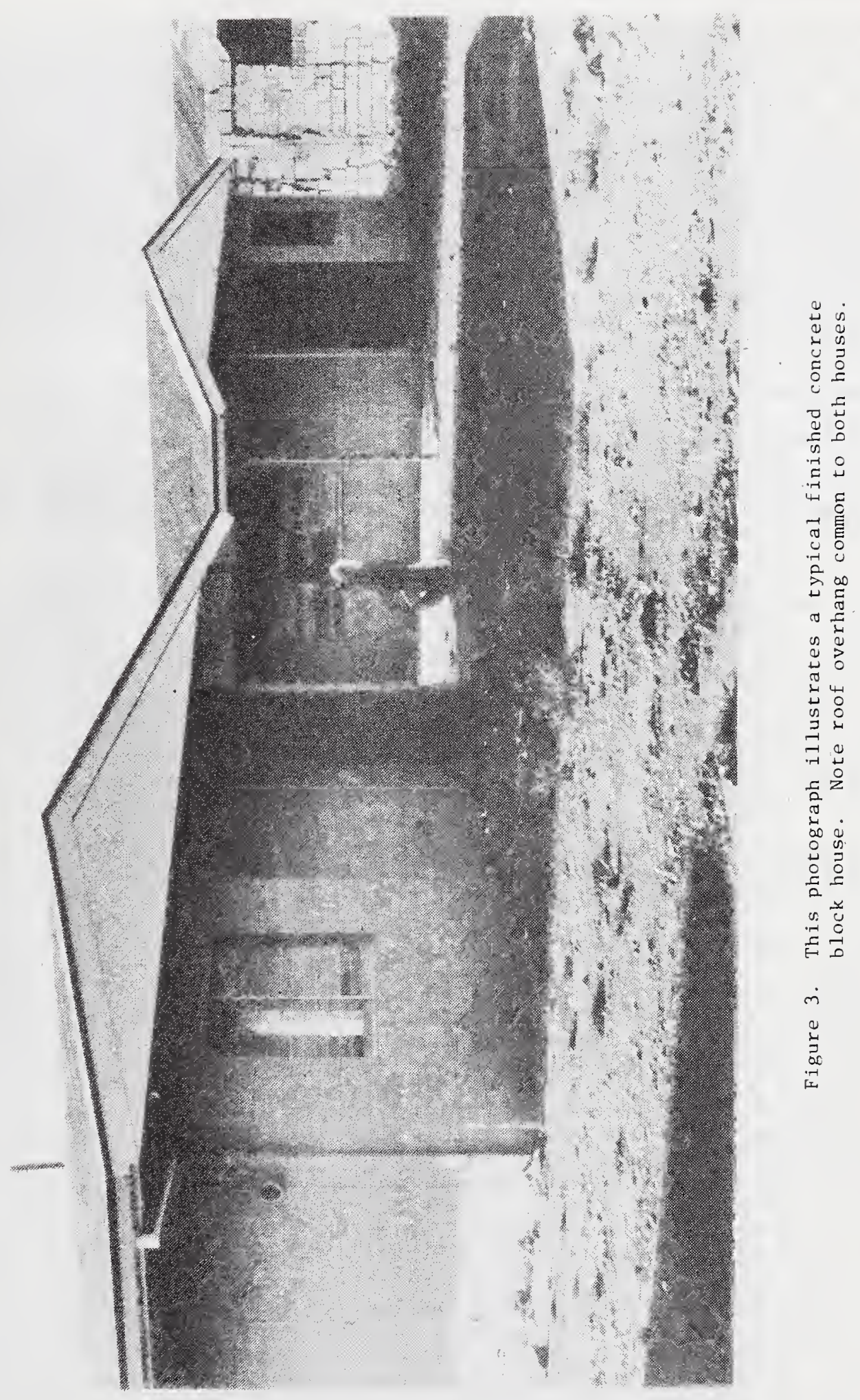


h. Other Philippine Organizations (Refer to Appendix A parts 2.h-o)

These organizations were invited by the University to attend an organizational meeting on April 27, 1973 at the Weather Bureau. At this time the research project was presented by the NBS team in detail to all the attendees. A question and answer period followed. After the presentation, an advisory committee was formed for the coordination of all Philippine activities associated with this research. The committee consisted of the groups listed in Appendix A parts 2.a-o. Dr. Tabujara was elected Chairman and General Tobias as Vice Chairman. In addition, a subcommittee was formed consisting of 5 committee members. The subcommittee's objectives are to schedule activities and establish estimates of the human and financial resources required for the Advisory Committees' recommended level of activity in this project. Colonel A. R. Kabiling of the National Housing Corporation, was elected Chairman of the subcommittee. A general feeling prevailed among a11 the attendees at the end of the meeting that there is deep Philippine interest in the project.

3. Dacca, Bangladesh

a. USAID Mission and U.S. Embassy

The persons listed in Appendix A, parts 3.a and b were visited on several separate occasions to describe the research project. The Mission and Embassy look forward to receiving results from the project.

Almost daily, stories from the field reported high wind damage in which homes and personal belongings have been swept away and people have been killed by flying debris. In Bangladesh the situation is almost beyond belief. This desperately poor and hungry country of 80 million people living in an area the size of Wisconsin have no method to seek government emergency housing relief (such as provided by our Office of Emergency Preparedness, HUD). Thus, as one might expect USAID's major concern is to provide assistance today to help reduce today's problems. Their activities are not geared to long range assistance. However, the AID Mission in Bangladesh agreed that this research project is certainly an important step toward the development of improving their housing plan.

The AID office offered any assistance we may need for future contacts or coordination of activities. They can provide effective indigenous advice from their professional staff should such be necessary.

b. CARE, Incorporated

In Bangladesh, CARE, Inc. is concerned with developing low-cost wind resistant structures. In this respect their involvement in Bangladesh currently centers around providing three different building concepts; a dome shaped house, a quonset shaped structure and a soil stabilized block house. The former design approach (see fig. 4) has not been put into production due to the local cultural nonacceptance of dome shaped buildings. At its present site it is used as a community health station. This structure is composed of 5 separate pieces. When joined together they form a decahedron shaped structure. The second design concept and latest design approach involves a precast on site building using three layers of polyester resin reinforced with jute (see fig. 5). This structure may be designed in incremental lengths of approximately one meter. This house also may be constructed with a veranda at one or both ends. The house shown in the figure is $5.4 \mathrm{~m}$ long ( $6-0.90 \mathrm{~m}$ sections per side) with an enclosed length of $4.5 \mathrm{~m}$. The windows and doors are formed while in the mold. As evident from the photograph, this design is based upon joining $0.90 \mathrm{~m}$ half arch sections together at the top to form an arch and then to the ground or a low brick wall by thin metal rods (see fig, 6). The soil stabilized block house concept (cinva-ram) uses aboi1t 6 percent of cement for soil stabilization. One hundred forty-eight houses were recently constructed using the cinva-ram method in a village $70 \mathrm{~km}$ west of Dacca (see fig. 7). Since these houses are relatively new, little data is available as to their success in resisting high winds. 


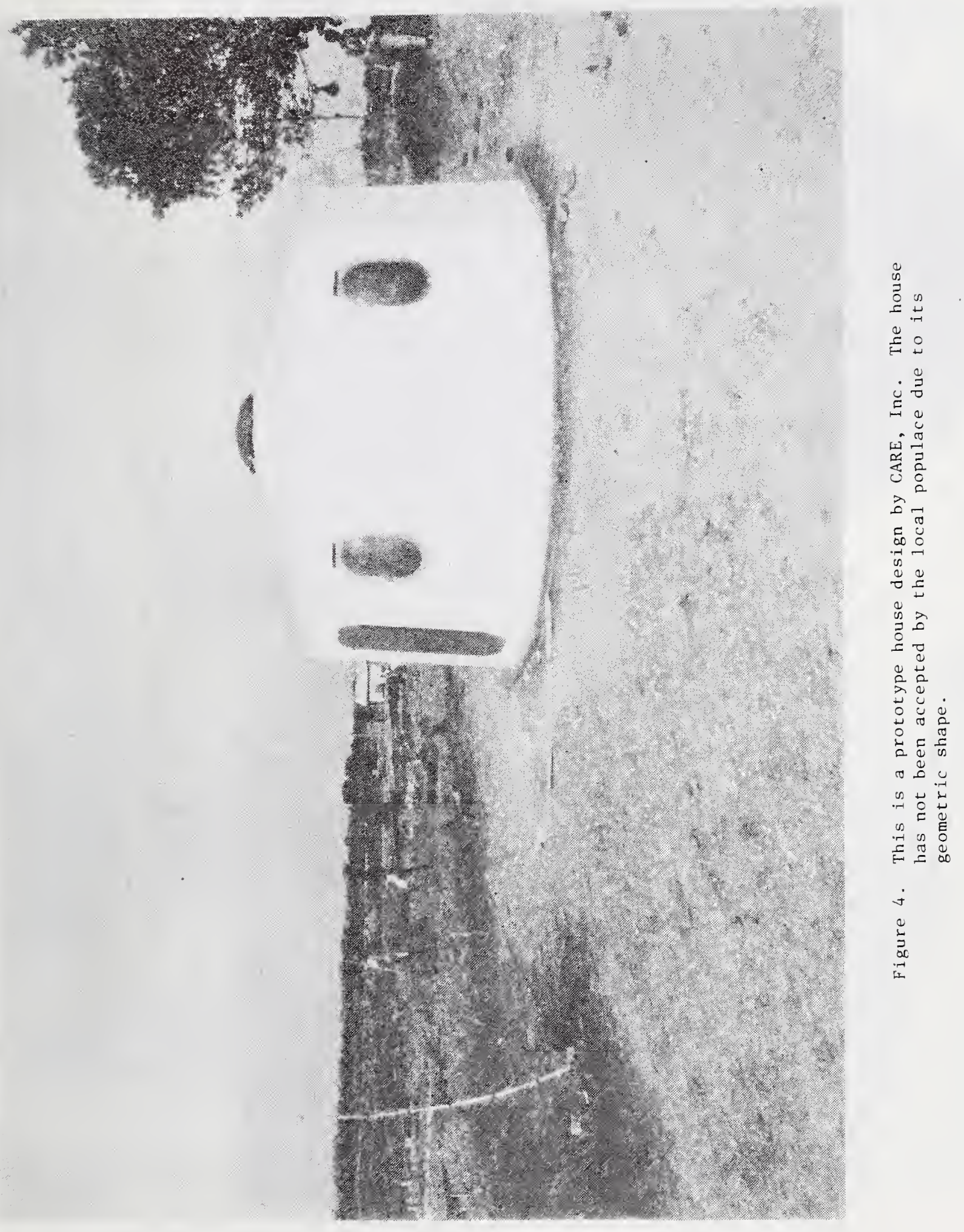




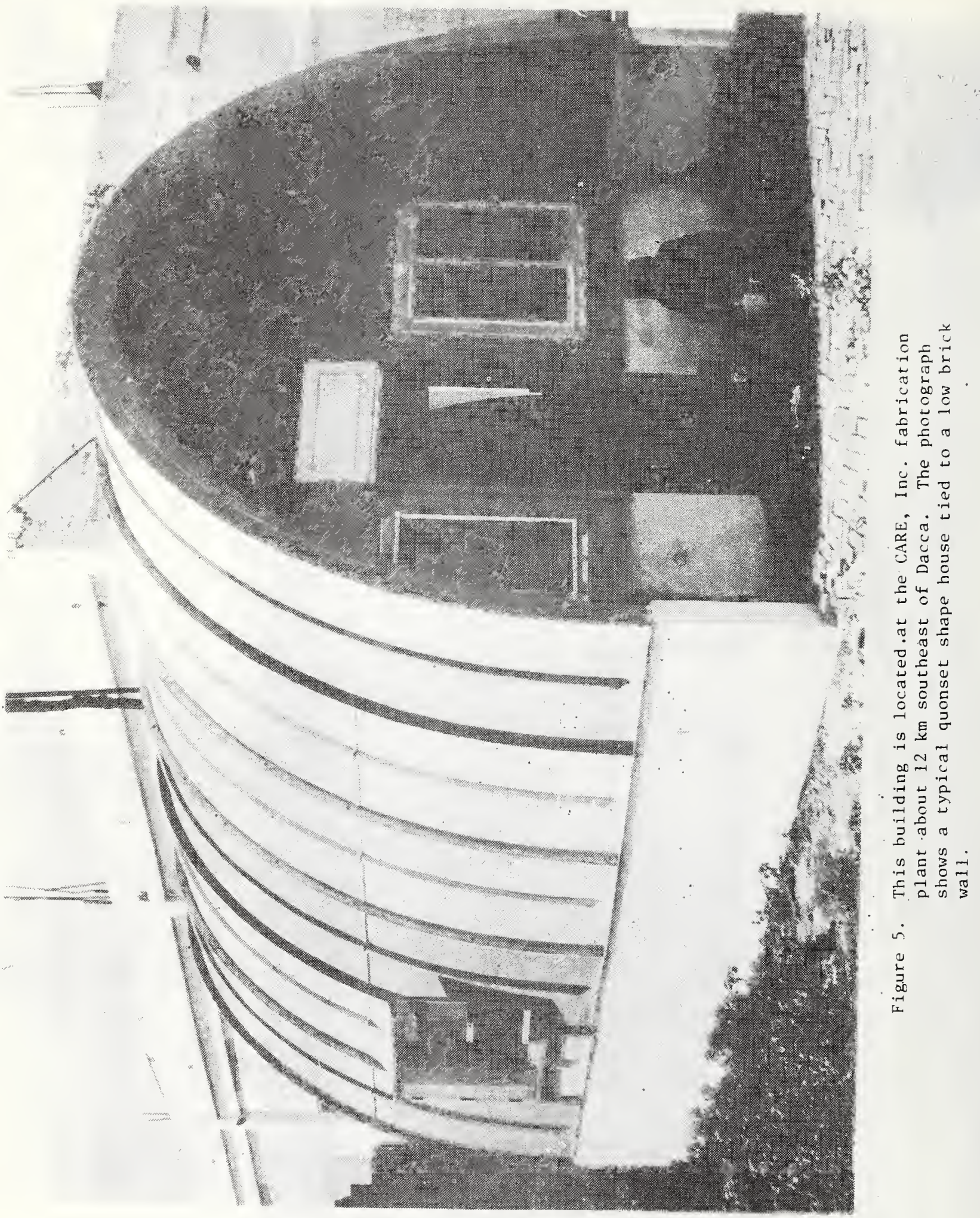




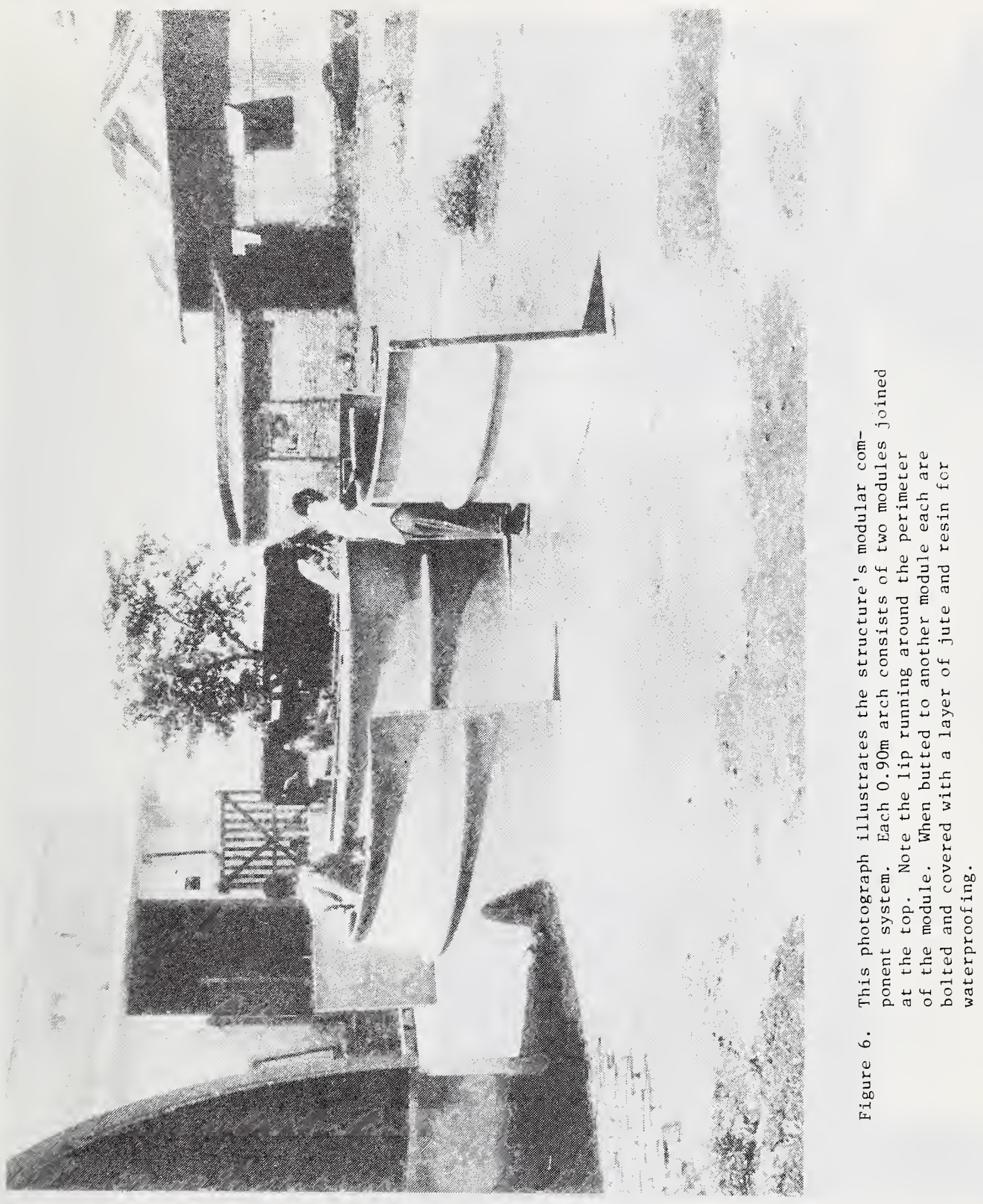




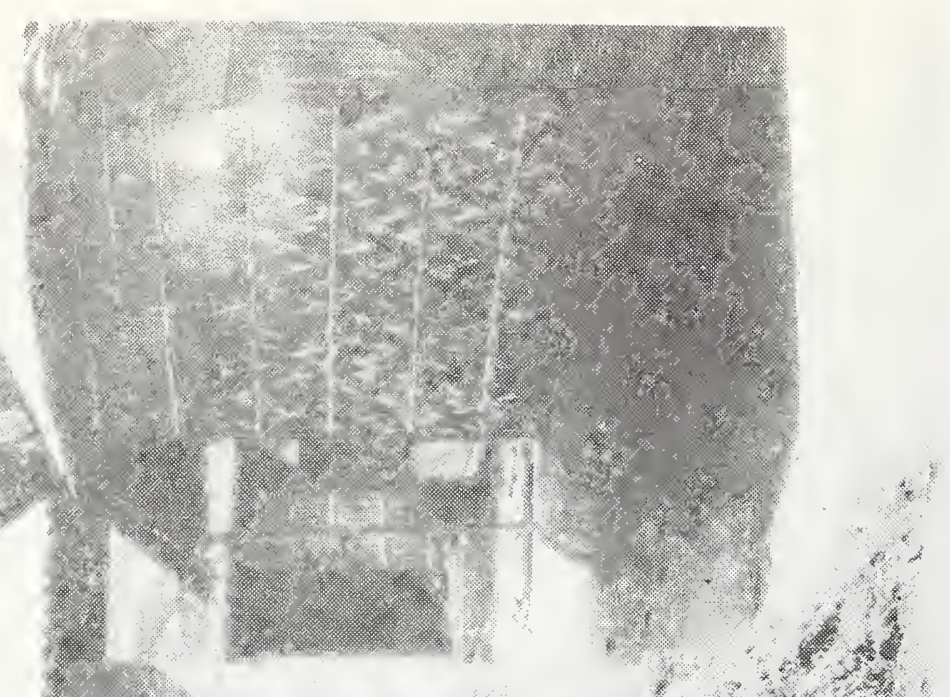

,
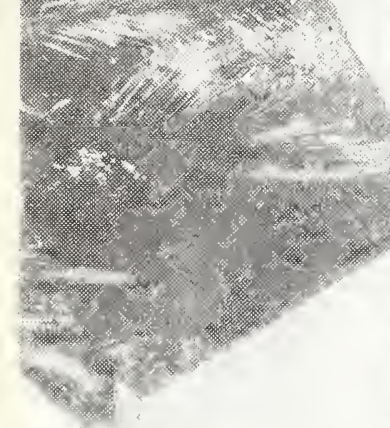

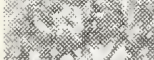

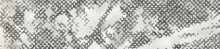

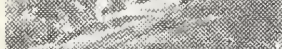

,

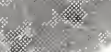


Of the three building designs the quonset type building appears to offer the greatest potential for providing low-cost locally acceptable housing to the Bangalis.

c. Bangladesh University of Engineering and Technology

Dr. Fazlur Khan, partner in Skidmore, Owings and Perrill, Architects (SOM), Chicago, identified Dr. Jamilur Choudhury as a candidate with whom to contract on a short term basis to provide a "transfer of knowledge" link between activities in the Philippines and the Indian Ocean countries. A meeting was scheduled with Dr. Choudhury and the project was discussed in detail. Dr. Choudhury then scheduled a briefing with $\mathrm{Dr}$. Islam who is in charge of the University's wind tunnel activities.

The wind tunnel in the Mechanical Engineering Department is an open return type with a test section of $0.25 \mathrm{~m}$ square and $0.60 \mathrm{~m}$ long. The maximum wind speed is $50 \mathrm{~m} / \mathrm{s}$. A new test section is scheduled to be constructed in the near future with speed of $70 \mathrm{~m} / \mathrm{s}$. This tunnel will be a closed return system with the drive motor located on the same plane as the test section. The university has a very minimal computer capability.

Both Drs. Choudhury and Islam are very interested in this project because they are performing similar, but less sophisticated research.

A proposal was received from Dr. Choudhury for review by NBS.

d. Shaheedulla and Associates - Consulting Structura1 Engineers

A meeting was held with $\mathrm{Mr}$. Shaheedulla, a private structural engineer in Dacca, (also referred by Dr. Fazlur Khan), who was presented a description of the project and was requested to indicate his degree of interest. He provided NBS with some ideas for reducing wind loads on buildings through use of barriers and tie-downs and a history of high winds in Bangladesh. Mr. Shaheedulla has experience in medium rise structures. He is being considered for a short term contract award.

e. Building Research Institute

This institute consists of a 3 man staff, 1 draftsman and 2 engineers. Mr. Hossian, Chief Engineer, was briefed and showed an interest in this study. To date, no information has been received from Mr. Hossian. BRI's capabilities are limited both in funding and human resources.

4. Garston, Watford, England

a. Building Research Establishment

Meetings were conducted with personnel noted in Appendix A, part 4.a. Each individual was briefed about the project and their assistance was requested in furnishing NBS with any related "lessons learned" information, e.g.

- how to design, install and use wind tunnel equipment to perform $1: 50$ scale modeling,

- what simulation methods are the most reliable,

- what would be done differently if BRE had to perform similar tests over,

- what are BRE recommendations for this study, and

- provide NBS with related research reports, etc.

Most of the BRE model studies are performed at Bristol University using a $1: 250$ scale. The tunnel most used for this type modeling at BRE is about 2 m wide by $1 \mathrm{~m}$ high by $6.5 \mathrm{~m}$ in length. The wind speed in this tunnel ranges from 0.75 to $5.0 \mathrm{~m} / \mathrm{s}$. Their second tunnel, an environmental tunnel, is an open return system with dimensions of $2.50 \mathrm{~m}$ by $1.80 \mathrm{~m}$ by $4.90 \mathrm{~m}$ long and produces a maximum wind speed of $10 \mathrm{~m} / \mathrm{s}$. The environmental tunnel, however, has no room for development of a boundary layer such as is required in our scale modeling activities. 


\section{a. University of Sydney, Department of Civil Engineering}

Wind-tunnel modeling techniques were discussed with Dr. B. J. Vickery. The tunnel used for wind studies at the University of Sydney is an open-return type with the fan installed at the intake. The working section is $1.80 \mathrm{~m} \mathrm{high,} 2.50$ $\mathrm{m}$ wide and $15 \mathrm{~m}$ long. The ceiling is nonadjustable and consists of perforated hardboard. This, coupled with the upstream fan position, results in a negligible pressure gradient and eliminates the problem of flow distortion caused by tunnel leakage. The cost of the tunnel, excluding the propellor and drive motor, was less than $\$ 3,500$ Australian $(\$ 5,200 \mathrm{U} . \mathrm{S})$. Instrumentation consists of hot-wire anemometers, a digital correlator-probability analyzer, a sampling multimeter and dynamic mounts for aeroelastic studies.

The problem of establishing a suitable boundary layer in the UP tunnel was discussed. It was Dr. Vickery's opinion that, while the existing tunnel in the Philippines would probably be satisfactory for the studies envisioned for the next three years, serious consideration should be given to the construction of a larger facility patterned after University of Sydney facility. It was also his opinion that special-purpose analyzers offer a cheaper means of processing wind tunnel data then can be accomplished with digital computers.

6. Melbourne, Australia

a. Monash University, Department of Mechanical Engineering

The Department of Mechanical Engineering operates a closed-return tunnel with a 2-meter square test section and a length of 15 meters. This tunnel is rather unique in that two models can be installed simultaneously, one model being placed in the pre-contraction section and one in the normal working section. Support equipment is quite similar to that used at the University of Sydney with the exception that random data are recorded and converted to digital form for computer processing. However, they intend to make more use of special-purpose analyzers in the future.

The facility is under the direction of Dr. W. H. Melbourne who is also conducting studies on full-scale structures. A number of useful suggestions were offered by Dr. Melbourne concerning wind tunnel and full-scale instrumentation. of particular note were his comments concerning the training of personnel to conduct model studies of buildings. He feels that training of one or two UP staff members could best be accomplished by having them visit an operating facility for two or three weeks and take an active part in testing and data analysis.

b. Division of Building Research, Commonwealth Scientific and Industrial Research Organization (CSIRO)

The scope and objectives of the AID/NBS Philippine project we re discussed with senior staff members of DBR. While no wind-load research programs are currently contemplated by DBR, they expressed much interest in the project and offered a number of suggestions on the structural aspects of the study.

The Light Timber Framing Code has recently been revised and new recommendations for structural connections have been made on the basis of tropical storm damage at Townsville, Queensland this past year. Several documents were obtained from DBR, including a copy of a report by Mr. I an Langlands concerning the establishment of the Building Research Service at the University of the Philippines. Unfortunately it was not possible to meet with Mr. Langlands during this visit. 
Equipment required to conduct the research program can be conveniently divided into three categories as follows:

1. Equipment for the instrumentation of full-scale buildings

2. Wind tunnel test equipment

3. Data reduction and analysis equipment

Equipment under category (1) is essentially a duplication of field test equipment purchased by NBS for remote and unattended acquisition of wind load data at remote field sites. Some equipment requires modification for operation in tropical climates and typhoon winds accompanied with intense rainfall. It is anticipated that up to three separate systems will be in operation during FY74 and that one of these systems will be deployed before the end of the current typhoon season. The basic components of a typical system are as follows:

- Anemometer and wind direction vane,

- Pressure transducers (10),

- Logic and signal conditioning unit,

- Time code generator,

- Analog tape recorder,

- Power supply,

- Equipment enclosure, and

- Meteorological tower.

With the exception of the time code generator and analog tape recorder, the above items, sufficient for one system, were purchased during FY73.

Equipment under category (2) will be used in conjunction with the wind tunnel facility at the University of the Philippines. The primary components are as follows:

- Hot wire anemometers (2),

- Pressure transducers (10),

- Manometer,

- Digital voltmeter,

- Oscilloscope,

- Pitot probes, and

- Test chamber.

These items, excluding the manometer and digital voltmeter, were purchased in FY73. While these equipment items are primarily intended for wind tunnel testing, the digital voltmeter, oscilloscope and test chamber will also be used to service and calibrate equipment listed under categories (1) and (3).

Equipment under category (3) will be used to analyze both ful1-scale and wind tunnel data and consists of the following major items.

- Signal correlator and probability analyzer,

- Stripchart recorder,

- X-Y plotter,

- Time code generator/reader, and

- Analog tape recorder.

Only the first of these items was purchased during FY73, the remaining items having a lower priority on the time schedule proposed for FY74.

As previously mentioned, to avoid duplication and to better integrate new equipment with that already available at the University of the Philippines, procurement of equipment was not initiated until after completion of a site visit in April. Delivery of most of the items purchased in FY73 is anticipated in July. 
The collection of related documents addressing the effects of extreme winds on low-rise structures serves two main purposes. First, it offers the opportunity to study the current state-of-the-art of extreme winds. And second these documents serve as a basis to transfer information to local Philippine agencies and organizations. In other words, the collection of wind related documents will be disseminated to the participating Philippine agencies and organizations as additions to their libraries. In addition, a bibliography of the Philippine documents will be sent to the other participating developing countries.

As a background to this task item, a short narrative of related activities is presented below. Shortly after award of contract, a meeting was conducted with NBS staff members to identify in-house related documents. These NBS staff members, in turn, gathered together a series of manuscripts, technical notes, and documents from various sources. For example; data collection activities have been initiated with the Department of State and in particular the United States Agency for International Developments' 1ibrary. Also, the 1ibraries of the National Oceanic and Atmospheric Administration, the Forest Products Laboratory, Portland Cement Association, the National Technical Information Service and universities are currently being requested to furnish wind related data. Additional documents are being received from the Building Research Establishment in Watford, England through a colaborative research program on wind loads on buildings.

\section{B. PROJECTED ACTIVITIES FOR FISCAL YEAR 1974}

The following section presents activities anticipated to be conducted during fiscal year 1974 .

\section{Transfer of Information}

To ensure effective transfer of research results to other developing countries, shortterm contracts will be awarded to local individuals in Bangladesh, a northern Caribbean country and with other groups as required. The individuals selected will have a working knowledge of their countries' housing problems and climatological conditions. It is expected that the consultants will collect and analyze information leading to the preparation of two reports dealing with the resistance of low-cost housing and other low-rise buildings exposed to extreme winds. These reports will address a broad range of low-rise, non-tourist type buildings, (e.g. housing, schools, community centers, etc.)

The first series of reports will be presented by the consultants at an organizational workshop meeting in Manila during the fall of 1973. The topics will include items such as:

1. Extreme wind related problems as found in their respective geographic area.

2. An outline of each country's (and respective geographic area) low-cost housing and low-rise building related problems and data gaps, both in the design (e.g. structural systems, connection details, design loads, etc.) and construction phases.

3. Related socio-economic considerations as they affect the design of structures.

In addition to the results arising from the above information exchange, NBS will assess the effectiveness of the project to dato in accomplishing its goals; evaluate the effectiveness and direction of the Philippine advisory committee; and redirect individuals as needed. This opportunity will permit NBS to alter activities and reschedule tasks as required.

The second series of reports will be prepared shortly after the consultants return from the Manila meeting. These reports will address the topics discussed during the meeting and will elaborate on problems associated with extreme wind loading of low-cost/low-rise buildings for the consultant's geographic area. An example of topics to be included are the following: 
1. Identification of housing trends and their design problems.

2. Influence of socio-economic considerations on housing patterns.

3. Survey and analysis of housing needs for the next ten years.

4. Collection and tabulation of available climatological data on extreme winds.

5. Collection and tabulation of wind damage statistics.

6. The applicability of alternative solutions for mitigating losses from high winds.

7. Definition of possible low-cost building design problem areas unique to each consultant's geographic area.

The NBS received correspondence from Dr. Choudhury and Mr. Shaheedulla expressing an interest in providing consulting services. These individuals are currently under review for a contract award.

Visit to Northern Caribbean Islands

Meetings with the Bureau of Standards, Society of Architects, Ministry of Public Works, the Ministry of Housing and the University of the West Indies in Kingston, Jamaica are scheduled. In order to maximize the transfer of information to Caribbean developing countries, it is planned that individuals and organizations in Haiti and the Dominican Republic with the appropriate qualifications be invited to attend the meeting in the Philippines.

Purchase of Equipment for Fiscal Year 1974

Typical components of instrumentation systems required for the research project have been itemized in an earlier section of this report. Components to be purchased and assembled in FY74 will satisfy requirements for wind tunnel testing and data analysis and will provide for three complete field instrumentation systems. It is possible that more than one full-scale structure can be served by a single data acquisition system.

Identification of Field Test Sites

The Philippine Advisory Committee, with the concurrence of NBS, will select 3 or 4 field sites for instrumenting full scale buildings. It is expected that several sites will be discussed for consideration during the international meeting before narrowing the choice down to 3 or 4 .

The identification of suitable field test sites depends upon a number of factors, including the frequency of tropical storms and typhoons, the type of terrain (wind exposure), the structure's availability, and its accessibility. In addition, commercial power must be available (other than during storm conditions when power outrages must be expected to occur) and the sites should be reasonably secure from flooding due to runoff or storm surge.

Obviously, some economy can be realized by instrumenting existing structures that satisfy the above requirements and that are geometrically and structurally similar to those housing systems which merit detailed study. On the other hand, structures erected specifically for this research program and located on Philippine Weather Bureau sites would allow for supplementary wind data, regular equipment maintenance and equipment security.

As a result of the field visit to the Philippines in April 1973, the NBS study team was able to assess the National Housing Corporation Plant north of Manila as a candidate test site. The reasons for considering this site are as follows:

1. Several innovative housing systems have been erected on the plant grounds and have been offered for use as test structures.

2. The site substantially satisfies the requirements or factors for site selection as listed above. 
3. The site is reasonably close to the University of the Philippines which will allow for periodic monitoring and maintenance by university personnel.

4. A field trip to the site to observe actual wind monitoring and testing will be arranged during the course of the international meeting scheduled in Manila later this year.

Based on discussions with Philippine Weather Bureau personnel, a second candidate site has been identified near Virac, Catanduanes (about $380 \mathrm{~km}$ Southeast of Manila). The mean annual crossing frequency of tropical storms in the Catanduanes area is relatively high. This island is also the site of a well-equiped weather station. If this site is selected, a housing system will have to be erected at the weather bureau site near the municipality of Virac.

It is hoped that selection of other sites will be made during the next six months after a more thorough analysis of climatological data has been completed. The choice of housing systems to be erected and instrumented will probably be deferred until after the fall meeting.

\section{Climatological Analysis of Data}

As discussed in the previous subsection, final selection of test sites must be based, in part, upon the probability of extreme winds occurring at the site. Also, the development of maps showing distributions of extreme winds over the Philippines is one of the goals of the research program.

Basically, this involves the tabulation of annual peak winds for a number of selected weather stations and the fitting of the resulting data series with appropriate extreme value probability distributions. Fortunately, considerable work has already been done on this problem by the Philippine Weather Bureau and distributions for various mean recurrence intervals are available. While subsequent studies may show that distributions other than the commonly used Type I provide a better fit, existing information is certainly suitable for site selection. Computer programs for establishing parameters of annual extreme winds and mean speeds corresponding to given mean recurrence intervals have been developed at NBS and will be used in the project. The Philippine Weather Bureau is now in the process of digitizing annul extreme wind speeds for all stations and it is anticipated that work on new distributions will be well under way in FY74. These records are based upon approximately 20 years of data which is generally considered adequate for the degree of statistical confidence required.

\section{Wind Tunnel Studies}

So that instrumentation can be properly positioned on full-scale structures to yield the most useful test data, it is advantageous to conduct preliminary wind tunnel studies on models of the test sites.

The model studies will be conducted at a scale between 1:75 or 1:100 in the University of the Philippines (UP) wind tunnel facility. The simulation of the atmospheric boundary layer will be the most critical and most difficult part of this task, requiring a trial and error procedure by persons having extensive experience in this type of work. This can best be accomplished by using a wind tunnel in the United States having dimensions and geometry similar to the UP facility. Once the technique is established to model the mean velocity profile and the scale and intensity of turbulence, it should be relatively simple to establish a similar flow in the UP tunnel. A survey of research centers indicates that Colorado State University is well qualified to carry out, under the technical supervision of NBS, this preliminary phase of wind tunnel testing.

The UP tunnel has a $1.22 \times 1.22 \mathrm{~m}$ test section with a useable length of $3.70 \mathrm{~meters}$. While this is satisfactory for most model tests anticipated during the program, serious thought may be required to evaluate the need to construct a new facility specifically designed for building research problems. This could contribute substantially to the establishment of a regional center for wind research in the Philippines. On the basis of a visit to the new wind tunnel now operating at the University of Sydney, it is believed that a tunnel could be constructed at the University of Philippine's for approximately $\$ 8,000$. This investment, at least in part, could probably be recovered during the course of the current 
program due to the simplification of modeling techniques and would allow future investigations in to more complex areas such as aeroelastic response problems.

\section{PRELIMINARY FISCAL YEAR 1974 PROJECT SCHEDULE}

The following table presents a summary of the major activities scheduled for FY74. These items are presented for illustration purposes and should not be considered as complete or inflexible. As activities are initiated the table may be adjusted to reflect appropriate changes. 


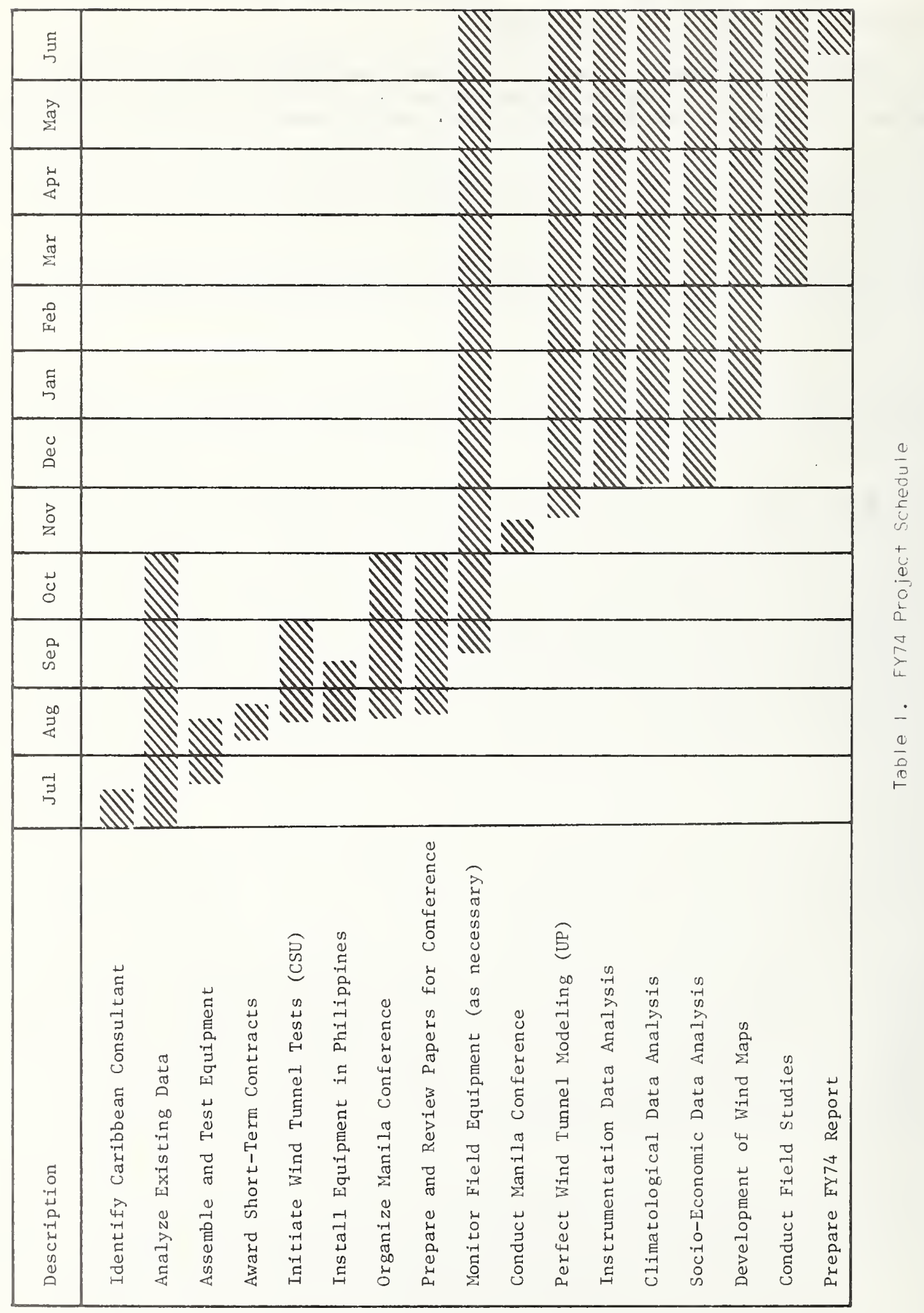


APPENDIX A

ORGANIZATIONS AND FACILITIES VISITED DURING THE APRIL 1973 FIELD TRIP 
During the initial field trip to Japan, Philippines, Bangladesh, England and Australia, contacts were made with many individuals. Among those contacted were the following:

1. Tokyo, Japan

a. U.S. Embassy

Mr. Richard H. Zorn II, Second Secretary, Deputy Scientific Counselor

b. Ministry of Construction, Public Works Research Institute'

Mr. Mitsuru Nagao, Director

Dr. Tadayoshi Okubo, Head, Structure and Bridge Section, Chiba Branch

Mr. Tatsuo Kawagoe, Director, Akabane Branch

Mr. Eiichi Kuribayashi, Chief, Earthquake Engineering Section, Chiba Branch

Mr. Hiroshi Yoshimura, Director, Planning Division

Mr. Saburo Matsuno, Chief, Planning Section

Dr. Masami Fukuoka, Professor of Civil Engineering, University of Tokyo

2. Mlanila, Republic of the Philippines

a. USAID Mission

Mr. William C. Larson, Assistant Director for Capital Development

Mr. Thomas E. Johnson, Deputy Assistant Director for Capital Development

b. University of the Philippines, Quezon City

Dr. Alfredo L. Juinio, Dean College of Engineering

Dr. Aurelio T. Juguilon, Dean College of Architecture

Dr. Ernesto G. Tabujara, Associate Professor of Civil Engineering

Mr. Angel A. Alejandrino, Professor of Engineering

Mr. Geronimo V. Manahan, Professor of Architecture

Dr. Josefina M. Ramos, Architect

c. Philippine Weather Bureau, Quezon City

Dr. Roman L. Kintanar, Director

Mr. Catalino P. Arafiles, Weather Specialist

Mr. Wellington A. Minoza, Weather Specialist

Mr. Hugo dela Cruz, Climatologist

Mr. Manuel Bonjoc, Weather Specialist

d. National Housing Corporation (NHC), Caloocan City

Major General G. V. Tobias, Executive Vice President

Col. Alejandro R. Kabiling, Vice President for Operations

e. Peoples Homesite and Housing Corporation (PHHC)

Lt. Col. Manuel Rebueno, Head Engineer, Planning and Survey Department

f. Economic Commission for Asia and the Far East (ECAFE)

Dr. Sudhindra Nath Senn, Chief, Typhoon Research Committee Secretariat

g. Land and Housing Development Corporation (LHDC), Quezon City

Col. Alberto R. Sanchez, Vice President (Operations)

h. Government Service Insurance System (GSIS)

Mr. Jose P. Orola, Chief, Engineering Department

Mr. Modesto Soriano, Assistant Division Chief, Engineering Department

i. Social Security Systems (SSS)

Mr. Miguel V. Paala, Chief Real Estate Department 
j. A. R. Flores and Associates, Consultants

Mr. Ambrosio R. Flores, President, Philippine Standards Association

k. Concio and Associates

Mr. Cesar H. Concio, Architect

1. Association of Structural Engineers of the Philippines

Mr. Andres Hizon, President

m. Philippine Association of Civil Engineers

Mr. Cesar A. Caliwara, President

Mr. Octavio A. Kalalo, Vice President

n. Bureau of Public Works (BPW)

Mr. Rosalio A. Mallonga, Chief Structural Engineer

o. National Science Development Board (NSDB)

Mrs. Magdalena Templa, Chief, Division of Engineering, Industry and Trade

Mr. Romec Corduba

3. Dacca, Bangladesh

a. USAID Mission and U.S. Embassy

Mr. David Mandel, Chief Capital Development Division

Mr. Dave Wilson, AID Coordinator

Mr. Edward A. Glaeser, AID Coordinator

Mr. Roy Haftorson, Chief Engineer

Mr. S. A. F. Rahman, Engineer

Mr. Marvin Brenner, Administrative officer

Mr. Piere H. Jabbour, Budget and Fiscal officer

b. CARE, Incorporated

Mr. George Taylor, Director

Mr. William Woudenberg, Designer

c. Bangladesh University of Engineering and Technology

Dr. Obaidul Islam, Associate Professor Mechanical Engineer

Dr. Jamilur R. Choudhury, Associate Professor Civil Engineering

d. Shaheedulla and Associates

Mr. S. M. Shaheedulla, Consulting Engineer

e. Building Research Institute

Mr. Hossian, Chief Engineer, Housing

Mr. Zahiruddin, Chief, Architect Building Department

4. Garston, Watford, England

a. Building Research Establishment, Department of the Environment

Dr. S. Bate, Chief Division of Structural Engineering

Dr. Keith J. Eaton, Senior Research Officer

Dr. J. B. Menzies, Section Head

Dr. Nick Cook, Wind Tunnel Analyst

Mr. J. R. Mayne, Wind Research officer

5. Sydney, Australia

a. University of Sydney, Sydney, NSW

Dr. B. J. Vickery, Department of Civil Engineering 
6. Melbourne, Australia

a. Monash University, Clayton, Victoria

Dr. W. H. Melbourne, Department of Mechanical Engineering

Dr. R. Barden, Head, Department of Mechanical Engineering

b. Division of Building Research, CSIRo, Highett, Victoria

Dr, R. W. R. Muncey, Chief

Dr. F. A. Blakey, Assistant Chief

Mr. N. H. Cloot, Research Officer

Mr. G. F. Reardon, Research Officer

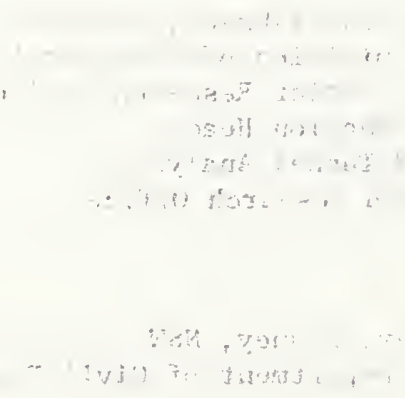


APPENDIX B

BIBLIOGRAPHY RELEVANT TO THE NBS/USAID WIND PROJECT 
FY73.

The following bibliography is a preliminary list of related documents collected through

Cook, N. J., "On Simulating the Lower Third of the Urban Adiabatic Boundary Layer in a Wind Tunne1," University of Bristol Report No. NJC 7301.

Templin, R. J., "Interim Progress Note on Simulation of Earth's Surface Winds by Artificially Thickened Wind Tunne1 Boundary Layers," NAE Report LTR-LA-22, February 1969.

Standen, N. M., "A Spire Array for Generating Thịck Turbulent Shear Layers for Natural Wind Simulation in Wind Tunnels," NAE Report LTR-LA-94, May 1972.

Melbourne, W. H., "Comparison of Pressure Measurements Made on a Large Isolated Building in Full and Model Scale," Paper No. 11-8, Proceedings of International Conference, Wind Effects on Buildings, Tokyo, 1971 .

Standen, N. M., Daleliesh, W. A., and Templin, R. J., "A Wind Tunnel and Full-Scale Study of Turbulent Wind Pressures on a Tall Building," Paper No. 11-3, Proceedings of International Conference, Wind Effects on Buildings, Tokyo, 1971.

Australian Standard CA-38-1971, SSA, Light Timber Framing Code

Bickford, J. M., "The Design of Single and Double Storey Hurricane Resistant Buildings," No. 18, Long Civil Engineering Course, Royal School of Military Engineering, Chatham, Kent, May 1972 .

Newberry, C. W., "A Study of Wind Pressures on Buildings as Revealed by Cyclones in Mauritius," Building Research Note No. B225, September 1960.

Mackey, S., Finney, C. and Okubo, T., "The Typhoons of October and November 1970," UNESCO Report No. 2387, Paris, May 1971.

Thom, H. C. S., "Distribution of Extreme Winds Over Oceans," Paper No. 9556, Journal of the Waterways, Harbors and Coastal Engineering Division, ASCE, February 1973.

Langlands, Ian, "Report on Assignment as Consultant on Building Research to the Institute of Planning of the University of the Philippines Special Fund Project," Manila, May 1972.

Davenport, A. G. and Dalegliesh, W. A., "A Preliminary Appraisal of Wind Loading Concepts of the 1970 Canadian National Building Code," Paper No. 111-5, Proceedings of International Conference, Wind Effects on Buildings, 1971.

Kintanar, Roman L., "An Analysis of Extreme Wind Speeds Over the Philippines," Regional Seminar on Wind Effects on Buildings and Structures, Manila, November 1971.

British Standard Code of Practice CP3, Chapter V, Part 2, 1970 . Wind Loads.

"Wind Loads on Buildings and Structures," Building Science Series 30 , National Bureau of Standards, Washington, D. C., November 1970.

American National Standard A58.1. Minimum Design Loads in Buildings and Other Structures, 1972 .

Sycip, Gorres, Velayo and Co., "Research Study of the Socio-Economic Aspects of Low-Cost Housing in the Philippines," Program Report to the National Bureau of Standards, May 1972. 
Nayle, W. J., Regetz,F., "Pre-Investment Survey Report Houstng Guaranty Program Th, l'hilippines 1972," March 1972 .

Sommer, A., Mosley, W. H., "East Bengal Cyclone of November 1970," The Lancet, Saturday May 13, 1972, pgs. 1029-1036. 
NBS-114A \{REV.7-73\}

\begin{tabular}{|c|c|c|}
\hline $\begin{array}{l}\text { I. PUBLIC.ATION OR REIPOKT NO. } \\
\text { NBSIR 74-582 }\end{array}$ & $\begin{array}{l}\text { 2. Gov'c Accession } \\
\text { No. }\end{array}$ & 3. Recipiene's Accession Nes. \\
\hline \multirow{2}{*}{\multicolumn{2}{|c|}{$\begin{array}{l}\text { 4. TITLE ANY } 73 \text { Progress Report on Design Criteria and Methodology for } \\
\text { Construction of Low-Rise Buildings to Better Resist Typhoons } \\
\text { and Hurricanes }\end{array}$}} & $\begin{array}{l}\text { 5. Publication Date } \\
\text { October } 1974\end{array}$ \\
\hline & & 6. Performing Organization Code \\
\hline \multicolumn{2}{|l|}{$\begin{array}{l}\text { 7. AUTHOR(S) } \\
\text { Raufaste, N. J.; Marshal1, R. D. }\end{array}$} & $\begin{array}{l}\text { 8. Performing Organ. Report No. } \\
\text { NBSIR 74-582 }\end{array}$ \\
\hline \multirow{2}{*}{\multicolumn{2}{|c|}{$\begin{array}{l}\text { 9. PEREORMING ORGANIZATION NAME AND ADDRESS } \\
\text { NATIONAL BUREAU OF STANDARDS } \\
\text { DEPARTMENT OF COMMERCE } \\
\text { WASHINGTON, D.C. } 20234\end{array}$}} & $\begin{array}{l}\text { 10. Pruject/Task/Work Unit No. } \\
\text { Center for Bldg. Tech. }\end{array}$ \\
\hline & & $\begin{array}{l}\text { 11. Contract/Grant No. } \\
\text { PASA No. TA(CE) } 04-73\end{array}$ \\
\hline \multirow{3}{*}{\multicolumn{2}{|c|}{$\begin{array}{l}\text { 12. Sponsoring Organization Name and Complete Address (Street, City, State, ZIP) } \\
\text { United States Agency for International Development } \\
\text { Department of State } \\
\text { Washington, D.C. } 20523\end{array}$}} & $\begin{array}{l}\text { 13. Type of Repott \& Period } \\
\text { Covered }\end{array}$ \\
\hline & & \\
\hline & & 14. Sponsoring Agency Code \\
\hline
\end{tabular}

15. SUPPLEMENTARY NOTES

16. ABSTRACT (A 200-word or less factual summary of most significant information. If document includes a significant bibliography or literature survey, mention it here.)

This report highlights the major accomplishments of the initial phase of a three fiscal year project to provide engineering technical assistance to the Agency for International Development (AID) for the development of design criteria for low-cost/low-rise buildings to better withstand the effects of extreme winds. This phase represents approximately a 3 month level of effort. During this period CBT project staff members commenced six introductory tasks. These tasks will set the pace for the second fiscal year level of effort. The tasks included: initiate dialogue with local orgainizations and institutes in developing countries, establish a local Philippine advisory committee; conduct on-site visits to developing countries to identify local professional candidates for short term consultating; conduct on-site visits to developed countries to collect information from research centers; purchase initial wind tunnel and full-scale field test instrumentation; and commence library search of related subject documents.

17. KEY WORDS (six to twelve entries; alphabetical order; capitalize only the first letter of the first key word unless a proper name; separated by semicolons) Construction; Design criteria; Extreme winds; Full-scale test buildings; Housing; Instrumentation; Wind tunnel

18. AVAILABILITY

For Official Distribution. Do Not Release to NTIS

Order From Sup. of Doc., U.S. Government Printing Office Washington, D.C. 20402 , SD Cat. No. Cl3

Order From National Technical Information Service (NTIS) Springfield, Virginia 22151

\begin{tabular}{|l|c|}
\hline $\begin{array}{l}\text { 19. SECURITY CL.ASS } \\
\text { (THIS REPURT) } \\
\text { UNCL ASSIFIED }\end{array}$ & 21. NO. OF PAGES \\
\hline $\begin{array}{l}\text { 20. SFCURITY CLASS } \\
\text { (THIS PAGE) } \\
\text { UNCLASSIFIED }\end{array}$ & 22. Price \\
\hline
\end{tabular}





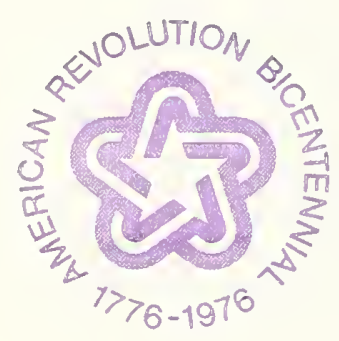

